University of Nebraska - Lincoln

DigitalCommons@University of Nebraska - Lincoln

Biological Systems Engineering: Papers and

Publications

Biological Systems Engineering

2009

\title{
Antiproliferation Properties of Grain Sorghum Dry Distiller's Grain Lipids in Caco-2 Cells
}

\author{
Richard Zbasnik \\ University of Nebraska-Lincoln, rzbasnik2@unl.edu \\ Timothy P. Carr \\ University of Nebraska-Lincoln, tcarr2@unl.edu \\ Curtis L. Weller \\ University of Nebraska-Lincoln, cweller1@unl.edu \\ Keum Taek Hwang \\ Seoul National University, Korea \\ Lijun Wang \\ North Carolina Agricultural \& Technical State University, Iwang@ncat.edu \\ See next page for additional authors
}

Follow this and additional works at: https://digitalcommons.unl.edu/biosysengfacpub

Part of the Biological Engineering Commons

Zbasnik, Richard; Carr, Timothy P.; Weller, Curtis L.; Hwang, Keum Taek; Wang, Lijun; Cuppett, Susan L.; and Schlegel, Vicki, "Antiproliferation Properties of Grain Sorghum Dry Distiller's Grain Lipids in Caco-2 Cells" (2009). Biological Systems Engineering: Papers and Publications. 189.

https://digitalcommons.unl.edu/biosysengfacpub/189

This Article is brought to you for free and open access by the Biological Systems Engineering at DigitalCommons@University of Nebraska - Lincoln. It has been accepted for inclusion in Biological Systems Engineering: Papers and Publications by an authorized administrator of DigitalCommons@University of Nebraska Lincoln. 


\section{Authors}

Richard Zbasnik, Timothy P. Carr, Curtis L. Weller, Keum Taek Hwang, Lijun Wang, Susan L. Cuppett, and Vicki Schlegel 


\title{
Antiproliferation Properties of Grain Sorghum Dry Distiller's Grain Lipids in Caco-2 Cells
}

\author{
Richard Zbasnik, ${ }^{1}$ Timothy Carr, ${ }^{2}$ Curtis Weller, ${ }^{3}$ Keum Taek Hwang, ${ }^{4}$ \\ Lijun Wang, ${ }^{3}$ Susan Cuppett, ${ }^{1}$ and Vicki Schlegel ${ }^{1}$
}

1. Department of Food Science and Technology, 143 Filley Hall, University of Nebraska-Lincoln, Lincoln, Nebraska 68583-0919

2. Department of Nutrition and Health Sciences, 316 Ruth Leverton Hall, University of Nebraska-Lincoln, Lincoln, Nebraska $68583-0806$

3. Department of Biological Systems Engineering, 210 Chase Hall, University of Nebraska-Lincoln, Lincoln, Nebraska 68583-0726

4. Department of Food and Nutrition, and Research Institute of Human Ecology, Seoul National University, Seoul 151-742, Korea

Corresponding author - V. Schlegel, tel 402 472-4694, fax 402 472-1693, email vschlegel3@unl.edu

Present address for Lijun Wang: Department of Natural Resources and Environmental Design,

North Carolina A\&T State University, 121 Sockwell Hall, Greensboro, North Carolina 27411

\begin{abstract}
Antiproliferative properties of lipids extracted from grain sorghum (GS) dry distiller's grain (DDG) were analyzed to determine the feasibility of developing GS coproducts as a source for human health dietary ingredients. The lipid extract of GSDDG was delivered to human colon carcinoma (Caco-2) cells by solubilizing 0-1000 $\mu \mathrm{g} / \mathrm{mL}$ of GS-DDG lipids in $100 \mu \mathrm{g} / \mathrm{mL}$ increments with micelles. A significant reduction in cell viability $(25-50 \%)$ resulted at treatment levels of $400-1000 \mu \mathrm{g} / \mathrm{mL}$ GS-DDG lipids $(p<0.05)$. Alternatively, total protein levels of cells treated with 400,500 , and $600 \mu \mathrm{g} / \mathrm{mL}$ of GS-DDG lipid were not significantly different from the control, indicating cell growth during the treatment period. Total cell counts for the control were not significantly different from the GS-DDG lipid treated cells, but dead cell counts increased by $\sim 10 \%$ for the latter sample with a concomitant increase of the intercellular protein lactate dehydrogenase leakage (30-40\%) in the medium. Preliminary analysis by the fluorescence-activated cell method (FACs) demonstrated that nonviable cells were in either the early apoptotic, late apoptotic, or necrotic stage post-treatment with 400, 500, and $600 \mu \mathrm{g} / \mathrm{mL}$ GS-DDG lipids. Physiochemical characterization of the GS-DDG lipids used for the antiproliferation study showed the presence of vitamin E (predominantly $\gamma$-tocopherol), triacylglycerides (predominantly linoleic acid), policosanols, aldehydes, and sterols (predominantly campesterol and stigmasterol), each of which or as synergistic/additive group of constituents may be responsible for the antiproliferative effect.
\end{abstract}

Keywords: grain sorghum, antiproliferation, ethanol, dry distiller's grain, Caco-2 cells

\section{Introduction}

The United States dominates sorghum production and distribution, accounting for $50 \%$ of the world's exports but most of our own supply is used as animal feed (1). In addition, $>1.3$ million metric tons of grain sorghum serve as raw material for ethanol per year, yielding $8.2 \mathrm{~kg}$ of distiller's dried grains with solubles (DDG) per $25 \mathrm{~kg}$ of grain sorghum (GS) (2). These statistics are expected to increase throughout the next decade to fulfill the 36 billion gallons per year renewable fuel mandate specified in the Renewable Fuels Standard by 2022 (3). Considering that the coproducts of dry-grind ethanol production are also distributed solely as animal feed, alternative applications for GS and its coproducts are needed to add value to this currently underutilized cereal.

Recent studies have shown that GS-DDG retains potentially valuable lipids at levels approximately 2-fold higher compared to their whole kernel counterpart (4). Composition analysis has further shown that the crude GS-DDG lipid fraction contains policosanols, aldehydes, triacylglycerides, hydrocarbons, tocopherols, phytosterols, free fatty acids, diacylglycerides, and vitamin E $(2,4,5)$. Many of these lipids are garnering attention due to their potential anticancer properties. For example, Awad et al. (6) demonstrated that the phytosterol, $\beta$-sitosterol, decreased in vitro breast cancer growth by $70 \%$, whereas campesterol had a weaker effect, reducing cell growth by $6 \%$. Epidemiology studies completed in Uruguay showed an inverse correlation between stomach cancer and phytosterol consumption (7). Campbell et al. (8) showed that the vitamin E isomer, $\gamma$-tocopherol, exerted a significant antiproliferation effect on two of the four immortal colon cancer lines studied. Evidence linking dietary fatty acids to anticancer properties has also been reported. Rats induced with mammary cancer but fed a diet high in olive oil had a $10 \%$ reduction in tumors compared to a corn oil based diet (9). These results were attributed to the high levels of $n-3$ polyunsaturated fatty acids in olive relative to corn oil, which contains higher levels of $n-6$ polyunsaturated fatty acids. 
Studies have yet to be completed that directly link GS-DDG lipids to anticancer benefits, but epidemiological data have shown reduced risks for gastrointestinal tract based cancers with GS consumption (1012). If anticancer agents are also present in the GS-DDG lipid extract, it is reasonable to expect that this coproduct can be developed as an ingredient source for the niche but fast-growing functional food and nutraceutical (FNNs) market. Consumption of such products is increasing to unprecedented levels, particularly in Japan, Europe, and the United States due to rising health care costs and aging populations $(13,14)$. The objective of this study was to characterize the antiproliferation effects on the human cancer colon cell line (Caco-2) in response to GS-DDG crude lipid extract. Compositional analysis of the crude lipid extract used for this study was also completed to provide preliminary data on the possible agent(s) responsible for eliciting the healthbenefiting responses.

\section{Materials and Methods}

Preparation of GS-DDG Lipid Extracts. A sample of GS-DDG was obtained from the U.S. Energy Partners facility located in Russell, KS. Lipids were extracted by recirculating $300 \mathrm{~mL}$ of hexane heated to $55^{\circ} \mathrm{C}$ over $200 \mathrm{~g}$ of GS-DDGs as described by Wang et al. (15). After an extraction period of $6 \mathrm{~h}$, the solvent was evaporated under vacuum, and the resulting residue was stored at $4-10{ }^{\circ} \mathrm{C}$ until needed.

Lipid Solubilization. Micelles were prepared by combining $221 \mathrm{mg} / \mathrm{mL}$ lecithin with $161 \mathrm{mg} / \mathrm{mL}$ cholesterol and transferred in 0.041-0.048 $\mathrm{mL}$ aliquots into vials. GS-DDG lipid samples were dissolved in hexane at $40 \mathrm{mg} / \mathrm{mL}$ and transferred in 1-10 mg aliquots into the lecithin/cholesterol mixture. The samples were dried under nitrogen while heating at $50{ }^{\circ} \mathrm{C}$ for at least $5 \mathrm{~min}$. Taurcholic acid sodium salt $(5.4 \mathrm{mg})$ was added to each vial followed by $10 \mathrm{~mL}$ of the growth medium, Delbecco's Modified Eagle Medium (DMEM). The samples were sonicated with an S-450D Branson digital sonifier (Danbury, CT) at 30\% amplitude for 2-3 min. The solubilized lipids were stored at refrigerated temperatures for a maximum of 3 days.

Culture Preparation. Human colon carcinoma cells (Caco-2) (American Type Culture Collection, Manassas, VA) were maintained in DMEM supplemented with $20 \%$ fetal bovine serum, $1 \%$ nonessential amino acids, $1 \%$ l-glutamine, and $50 \mu \mathrm{g} / \mathrm{mL}$ penicillin and streptomycin. The cells were cultured in $75 \mathrm{~cm}^{2}$ collagen-coated culture flasks at $37{ }^{\circ} \mathrm{C}$ and $5.0 \% \mathrm{CO}_{2}$. The cells were passaged with $3 \mathrm{~mL}$ of trypsin for $5 \mathrm{~min}$ after reaching $80 \%$ confluency. Tests were conducted at cell passage numbers of 30-50.

Cellular Proliferation. Cell proliferation studies were initially completed with 10 treatments of $100-1000 \mu \mathrm{g} / \mathrm{mL}$ solubilized GSDDG lipid extracts at $100 \mu \mathrm{g} / \mathrm{mL}$ increments. The cells were harvested by release with trypsin, counted with a Neubauer hemocytometer (VWR Scientifics, West Chester, PA) under a Microscoptics IV900 series microscope (VWR Scientifics), and centrifuged at $2900 \mathrm{rpm}$ for 5 min. The cells were resuspended in DMEM and dispensed in 96-well plates at $5 \times 10^{4}-1 \times 10^{5}$ cells/well. After allowing $24 \mathrm{~h}$ for cell recovery at $37^{\circ} \mathrm{C}$ in $5.0 \% \mathrm{CO}_{2}$, the medium was gently removed from each well and the lipid treatments were added. The plates were incubated for another $24 \mathrm{~h}$, and percent cell viability was assessed with the tetrazolium salt 3-(4,5-dimethylthiazolyl-2)-2,5-diphenyltetrazolium bromide (MTT) assay according to the manufacturer's instructions. The MTT reagent $(10 \mu \mathrm{L})$ was added to each well, and the plates were incubated at $37{ }^{\circ} \mathrm{C}$ and $5.0 \% \mathrm{CO}_{2}$ for another $2 \mathrm{~h}$. The cells were then lysed with $100 \mu \mathrm{L} /$ well of lysis buffer supplied with the MTT kit, followed by an additional $4 \mathrm{~h}$ of incubation. The absorbance (abs) was monitored at 580 and $620 \mathrm{~nm}$ with a FLOUstar Optima ELISA plate reader (BMG Labtech, Offenberg, Germany). Cell proliferation was calculated as \% viability $=($ sample abs $/$ control abs $) \times 100$. Results are reported as the percent viability \pm standard error of the mean (SEM) of six replicates for each treatment (four to six analyses per replicate).

The bicinchonic acid (BCA) protein assay was used to monitor overall cell growth in response to different lipid treatments. The cells were seeded into 96-well plates $\left(5 \times 10^{4}\right.$ cells/well) and maintained in DMEM for $24 \mathrm{~h}$. The medium was removed and replaced with 400, 500, or 600 $\mathrm{\mu g} / \mathrm{mL}$ of the solubilized GS-DDG lipid. The plates were incubated for another $24 \mathrm{~h}$, and the medium was carefully removed. Each well was washed with $50 \mu \mathrm{L}$ of phosphate-buffered saline (PBS) followed by another $50 \mu \mathrm{L}$ of PBS and $100 \mu \mathrm{L}$ of the MTT lysis buffer. After $1 \mathrm{~h}$ of incubation at $37^{\circ} \mathrm{C}, 50 \mu \mathrm{L}$ of lysate from each well was transferred to a clean well containing $150 \mu \mathrm{L}$ of PBS. BCA $(150 \mu \mathrm{L})$ was added to each well followed by incubation at $37^{\circ} \mathrm{C}$ for $2 \mathrm{~h}$. The absorbance was monitored at $544 \mathrm{~nm}$, and protein levels were determined against a calibration curve generated with bovine serum albumin. Results are reported as the mean \pm SEM of four replicates (three to four analyses per replicate).

Total and precent dead cell counts were determined with the Trypan Blue exclusion dye assay as described by Wijeratne et al. with minor modifications (16). A $100 \mu \mathrm{L}$ aliquot of the cells from the $12.5 \mathrm{~cm}^{2}$ flask treated with 400,500 , or $600 \mu \mathrm{g} / \mathrm{mL}$ of micellarized GS-DDG lipids was collected after harvesting with trypsin. Trypan Blue dye (100 $\mu \mathrm{L}$ ) was combined with the cells, and the total numbers of cells and of dead cells (stained) were counted on a Neubauer hemocytometer (VWR Scientifics) under a Microscoptics IV900 series microscope (VWR Scientifics). Percent dead cells was calculated as (stained cell counts $/$ the total cell count $) \times 100$. Total cell counts and percent dead cell counts are reported as the mean \pm SEM of three replicates (three to four analyses per replicate).

A lactate dehydrogenase (LDH) kit was used to determine cellular membrane damage in response to lipid treatments as outlined by the manufacturer with minor modifications. Cells were transferred to $12.5 \mathrm{~cm}^{2}$ culture flasks and allowed to recover in untreated DMEM for $24 \mathrm{~h}$ during incubation at $37^{\circ} \mathrm{C}$ and $5.0 \%$ carbon dioxide in the atmosphere. After recovery, the medium was aspirated from the cells and replaced with 400,500 , or $600 \mu \mathrm{g} / \mathrm{mL}$ of solubilized GS-DDG lipid, medium + micelles (control), or fresh medium only, medium micelles (blank). After $24 \mathrm{~h}, 100 \mu \mathrm{L}$ of medium from each treatment group, control, and blank was transferred to a 96-well plate. The LDH reagent was mixed with equal volumes of dye solution, substrate, and enzyme preparation and added at a volume of $50 \mu \mathrm{L}$ to each well. The plate was incubated at room temperature for $20 \mathrm{~min}$, and the reaction was stopped with $15 \mu \mathrm{L}$ of $1 \mathrm{~N} \mathrm{HCl}$. The absorbance was monitored at 485 and $680 \mathrm{~nm}$ with a FLOUstar Optima ELISA plate reader. To determine the total amount of intracellular LDH, the cells from the previous test were harvested from $12.5 \mathrm{~cm}^{2}$ flasks with trypsin and deactivated by DMEM. A sample $(500 \mu \mathrm{L})$ from each of the treatment groups, control, and blank was combined with $50 \mu \mathrm{L}$ of the TOX-7 lysis buffer and incubated at $37{ }^{\circ} \mathrm{C}$ with $5.0 \%$ carbon dioxide for 45 min. Aliquots $(100 \mu \mathrm{L})$ from each set of cells were plated onto a 96 well plate in triplicate. The LDH reagent was mixed with equal volumes of the dye solution, substrate, and enzyme preparation, which was added at a volume of $50 \mu \mathrm{L}$ to each well. The plate was incubated at room temperature for 20 min followed by deactivation with $15 \mu \mathrm{L}$ of $1 \mathrm{~N} \mathrm{HCl}$. The absorbance was monitored at 485 and $680 \mathrm{~nm}$ with a FLOUstar Optima ELISA plate reader. Percent LDH leakage was calculated by determining the net absorbance of $680 \mathrm{~nm}$ from $485 \mathrm{~nm}$ obtained from both the supernatant and cell lysis data and applying the following relationship: \% LDH $=$ (net abs of supernatant/(net abs of supernatant + net abs of cell lysate)). Results are reported as the mean percent $\mathrm{LDH} \pm \mathrm{SEM}$ of four replicates (three analyses per replicate).

Cellular necrosis and apoptosis in response to lipid treatments of 400, 500, and $600 \mu \mathrm{g} / \mathrm{mL}$ GS-DDG lipid were assessed by using the fluorescence-activated cell (FACs) method $(17,18)$. After treatment, cells were harvested and incubated with propidium iodide and fluorescent isothiocyanate-annexin $\mathrm{V}$ for 20-30 $\mathrm{min}$ at room temperature. The cells were loaded into the cuvette of a flow cytometer (Becton Dickinson FACScan, Franklin Lakes, NJ) and monitored at an excitation of $488 \mathrm{~nm}$ and an emission wavelength of $525 \mathrm{~nm}$ for the fluorescein isothiocyanate-annexin $\mathrm{V}$ or $575 \mathrm{~nm}$ for the propidium iodide. Results are reported as the mean \pm standard deviation (SD) of percent gated cells for one replicate (two analyses per replicate).

GS-DDG Lipid Characterization. Simple lipid classes present in the extract were initially identified and quantitated using thin layer chromatography (TLC). A cocktail of standards containing cholesterol, fatty acid methyl esters, d-a-tocopherol acetate, and three polyoxyethylenesorbitan monooleate, octacosanol, monoacylglcyerides of oleic acid, 1,2-diacylglycerols of oleic acid, 1,3-diacylglcyerides of oleic acid, and 
triacylglycerides of oleic acid was prepared. The GS-DDG lipid sample was suspended in hexane at a concentration of $25-30 \mathrm{mg} / \mathrm{mL}$. The samples/standards were spotted onto a Whatman silica $60 \AA$ TLC plate (60 general purpose, $20 \times 20 \mathrm{~cm}, 250 \mu \mathrm{m}$, Maidstone U.K.) using 10 and $5 \mu \mathrm{L}$ aliquots. The samples/standards were resolved with hexane, diethyl ether, and acetic acid [85:15:2 (v/v/v)]. The lipids were visualized by submerging the plate in $10 \%$ cupric sulfate in $8 \%$ phosphoric acid solution and charring at $165^{\circ} \mathrm{C}$ for $10 \mathrm{~min}$. The developed plate was scanned with a Kodak Gel Logic 440 Imaging System interfaced to Kodak ID Image Analysis software (Carestream Health, New Haven, CT).

A HPLC (Waters 510; Waters Corp., Milford, MA) equipped with a Luna $5 \mu \mathrm{m}$ silica column $(250 \mathrm{~mm}$ length, $4.6 \mathrm{~mm}$ id; Phenomenex, Torrance, CA) was also used to identify and quantify the several simple lipid classes. Detection was accomplished with an Alltech 800 evaporative light scattering detector (Deerfield, IL) operated at $50^{\circ} \mathrm{C}$. The nebulizer gas was nitrogen of industry grade, which was set at a flow pressure of 5.0 bar. Solvents consisting of $100 \%$ hexane (mobile phase A) and $99.8 \%$ hexane, $0.2 \%$ acetic acid, and $0.02 \%$ methyl tert-butyl ether (mobile phase B) set at a flow rate of $1 \mathrm{~mL} / \mathrm{min}$ were used to separate the lipids using the following linear gradient: $0 \mathrm{~min}, 100 \% \mathrm{~A} ; 2 \mathrm{~min}$, $100 \%$ A; 3 min, 95\% A; $10 \mathrm{~min}, 95 \%$ A; $14 \mathrm{~min}, 55 \%$ A; $15 \mathrm{~min}, 55 \%$ B; $23 \mathrm{~min}, 0 \% \mathrm{~A} ; 26 \mathrm{~min}, 0 \% \mathrm{~A}$. The column was heated to $38-40{ }^{\circ} \mathrm{C}$; other exposed lines were maintained at $38-40^{\circ} \mathrm{C}$ with heating tape. Chromatographic bands were identified and quantified with external standards. Results are expressed as the mean \pm SD of a resolved lipid component/total GS-DDG lipid (mg/g) of duplicate analyses.

Compositional analysis of the tocopherols was performed with a HPLC method described by Bruni et al. (19). In brief, the sample was dissolved in hexane at a concentration of $30-40 \mathrm{mg} / \mathrm{mL}$ and injected onto a silica gel Lichrosorb Si-60 column (Agilent Technologies, Santa Clara, CA) interfaced to a Beckman System Gold 127 NM Solvent Module HPLC (Beckman Coulter Inc., Fullerton, CA) and heated to 30-32 ${ }^{\circ} \mathrm{C}$. Isopropanol $(0.05 \%)$ in hexane served as the mobile phase, which was set at a flow rate of $1 \mathrm{~mL} / \mathrm{min}$. Analytes were detected at $295 \mathrm{~nm}$ with a Beckman System Gold 166 UV-vis detector. The tocopherol peaks were identified and quantified by comparison with $\alpha-, \gamma^{-}$, and $\delta$-tocopherol external standards. Results are expressed as the mean \pm SD of tocopherols/total GS-DDG lipid (mg/g) of triplicate analyses.

A carotenoid assay was performed with a HPLC method described by Craft (20). GS-DDG lipids $(2-3 \mathrm{mg})$ were dissolved in $0.25 \mathrm{~mL}$ of hexane and then combined with $0.25 \mathrm{~mL}$ of methanol. After continual shaking for $\sim 1 \mathrm{~h}$, the methanol phase was analyzed with a Waters 600 S HPLC (Milford, MA) system interfaced to a Waters Millennium 32 Chromatography Manager workstation. The samples were resolved using an Agilent Zorbax 300SB C-18 (Santa Clara, CA) column and a mobile phase of methanol, acetonitrile, and triethanolamine [90:10:1 $(\mathrm{v} / \mathrm{v} / \mathrm{v})]$ under isocratic conditions maintained at a flow rate of $1 \mathrm{~mL} /$ min. A Waters 996 photodiode array set at $450 \mathrm{~nm}$ was used as the detection mode. Results are not provided as carotenoids were not detected in triplicate analyses of the sample.

Quantification of sterols (free and esterified) was achieved with gas chromatography (GC) and flame ionization detection. GS-DDG lipids (10-20 mg) were prepared and analyzed according to the method of Schnieder et al. (21). The samples were injected $(1 \mu \mathrm{L})$ onto an HP 5890 Series II+ GC with a DB-1 column $(15 \mathrm{~m} \times 0.25 \mathrm{~mm})(\mathrm{J} \& W$ Scientific, Folsom, CA) under the following conditions: initial temperature, 190 ${ }^{\circ} \mathrm{C}$ for $1 \mathrm{~min}$, increased to 220 at $3{ }^{\circ} \mathrm{C} / \mathrm{min}$; injector temperature, 270 ${ }^{\circ} \mathrm{C}$; flame ionization detector temperature, $300^{\circ} \mathrm{C}$; helium carrier gas; and split ratio, 20:1. External standards of stigmasterol, campesterol, and $\beta$-sitosterol were used to identify and quantify the peaks. Results are expressed as the mean \pm SD of a sterol/GS-DDG lipid $(\mathrm{mg} / \mathrm{g})$ of triplicate analyses.

Fatty acid profiles were determined by adapting the American Oil Chemists' Society standard method Ce1b-89 (22) as follows. Boron trifluoride $(14 \%)$ in methanol was added to a sample and then was heated at $100{ }^{\circ} \mathrm{C}$ for $30 \mathrm{~min}$ in sealed reaction vials. The samples were allowed to cool to room temperature before extraction with $1 \mathrm{~mL}$ of hexane and three rinses of $2 \mathrm{~mL}$ of water. The hexane fraction and fatty acid standards were resolved with a Hewlett-Packard Co. 6890 series GC System Plus+ (Wilmington, DE) using a DB-Wax column (30 $\mathrm{m} \times 0.25 \mathrm{~mm}$ ) by J\&W Scientific and detected with a flame ionization detector. Injections were achieved with a split ratio of 10:1 with the temperature set at $185^{\circ} \mathrm{C}$ initially for $12 \mathrm{~min}$; the temperature was increased to 210 at $10^{\circ} \mathrm{C} / \mathrm{min}$, held for $0 \mathrm{~min}$, and then increased to a final temperature of 230 at $10^{\circ} \mathrm{C} / \mathrm{min}$, which was maintained for the remaining $15 \mathrm{~min}$ of the run. Results are expressed as the mean \pm SD of the relative percentage of each fatty acid of triplicate analyses.

Analysis of Data. Results were analyzed with R:A language and environment for statistical computing software (Vienna, Austria) and/or by StatsGraphic Plus, version 4 (Statpoint Technologies, Inc., Warranton, VA). Cell culture experiments were blocked for plates and time. The Cockran C test and Bartlet's test were performed to determine whether the variability between treatment results and the controls or from each other was significantly different at the $95 \%$ confidence interval $(p<0.05)$. If not, the Tukey HSD mean separation test was completed to determine whether the means from the cell culture data were significantly different at the $95 \%$ confidence interval $(p<$ 0.05). Statistical comparisons of the results based on the Tukey HSD mean separation test are therefore reported. The final results are expressed either as the mean \pm SEM when three to four replicates were completed and each replicate sample was analyzed multiple times or as the mean \pm SD when a single replicate was analyzed in duplicate or triplicate. Potential outliers were assessed with the Grubbs test at a 5\% risk for rejection.

\section{Results and Discussion}

Antiproliferation Study. The ability of GS-DDG lipids to inhibit cancer proliferation was evaluated using the human colon carcinoma cell line (Caco-2) as colon cancer is the second and fourth leading cause of cancer death in North America/Europe and worldwide, respectively (23-25). Moreover, grain sorghum consumption has been shown to be associated with reduced risks for gastrointestinal-based cancers (10-12). The antiproliferation properties of GS-DDG lipids $(100-1000 \mu \mathrm{g} / \mathrm{mL}$ in $100 \mu \mathrm{g} / \mathrm{mL}$ increments) were initially evaluated by monitoring the mitochondrial activity of GS-DDG lipid treated Caco-2 cells using the MTT assay. Because the GS-DDG samples were insoluble in the DMEM medium, micelles prepared with taurcholic acid sodium salt, lecithin, and cholesterol were able to solubilize the GS-DDG lipid at all treatment levels tested. While micelles have been used for delivering cholesterol and other sterols to mammalian cells (26), they are unique to a complex lipid extract. The data were thus normalized to the control (cells + micelles) as cell proliferation was affected by the micelle delivery system resulting in significantly lower percent cell viability compared to the blank (cells - micelles) (data not shown). As shown in Figure 1, percent cell viability decreased in a dose-dependent manner with significant differences (25-50\% reduction) occurring at treatment levels $\geq 400 \mu \mathrm{g} / \mathrm{mL}$. Percent viability was not significantly different for cells treated with $400-1000 \mu \mathrm{g} / \mathrm{mL}$ GSDDG lipids, indicating a limiting dosage of $400 \mu \mathrm{g} / \mathrm{mL}$.

The effective antiproliferative treatment levels and/or exposure time $(24 \mathrm{~h})$ used for this study were lower than reported for several other types of natural extracts and/or pure components. For example, Yang et al. (27) demonstrated that the polar extracts from different varieties of onion reduced Caco-2 proliferation at $\mathrm{EC}_{50}$ values between 30.5 and $141.1 \mathrm{mg} / \mathrm{mL}$. In addition, Kuntz et al. (28) reported that pure phenolic compounds, including different types of flavones, flavonols, flavanones, and isoflavones, reduced Caco-2 proliferation at $E_{50}$ values of $40-200 \mu \mathrm{M}$ and exposure times of $72 \mathrm{~h}$. Considering that a complex lipid extract is not widely recognized as an anticancer agent, particularly with respect to polar-based extracts or pure phenolics compounds, these results indicate that the GS-DDG lipids have effective antiproliferation properties.

The lowest level of GS-DDG lipid extract $(100 \mu \mathrm{g} / \mathrm{mL})$ administered in this study resulted in significantly lower cell viability, whereas cells exposed to dosage levels of $200-300 \mu \mathrm{g} / \mathrm{mL}$ were comparable to the control (Figure 1). Other researchers have reported similar but atypical responses for cells exposed to low doses of pure natural agents, that is, cell viability initially increased and then decreased or decreased, increased, and decreased again with higher treatment 


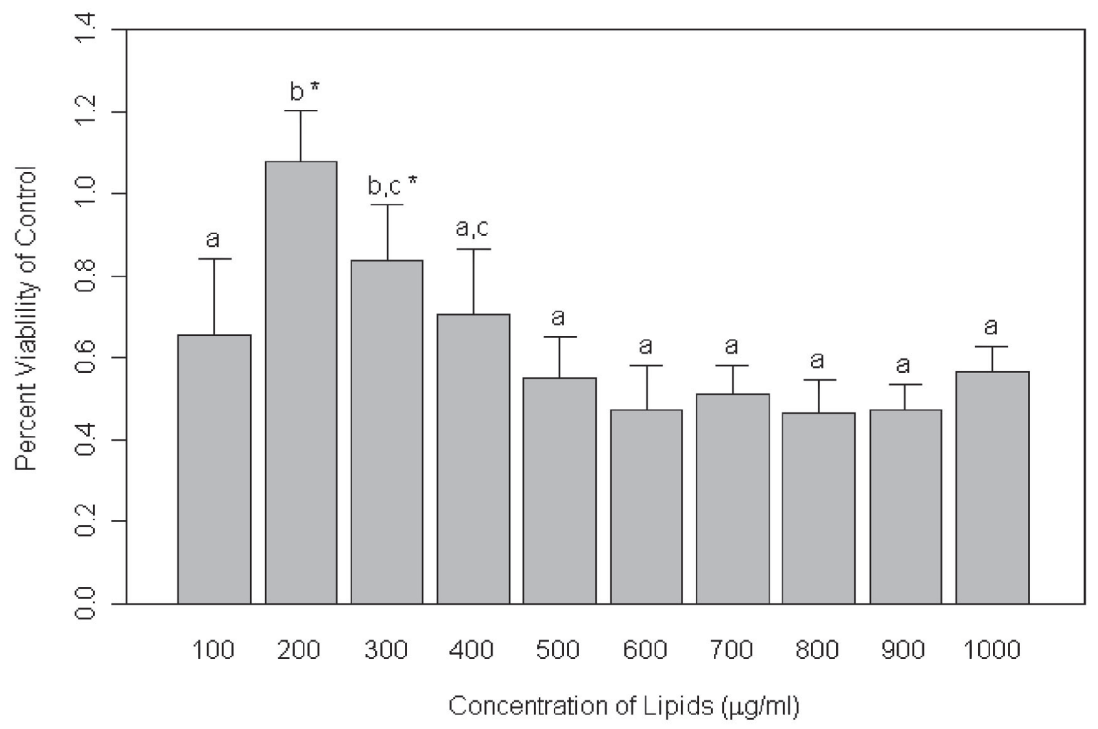

Figure 1. Percent cell viability based on the tetrazolium salt 3-(4,5-dimethylthiazolyl-2)-2,5-diphenyltetrazolium bromide (MTT) assay of Caco-2 cells treated with grain sorghum dry distiller's lipids (GS-DDG) (in $\mu \mathrm{g} / \mathrm{mL}$ ) as compared to the control $(0 \mu \mathrm{g} / \mathrm{mL}$ GS-DDG). Results that are significantly different $(p<0.05$ ) are designated with different letters from each other, whereas * represents results that are not significantly different $(p>0.05)$ from the control.

Table 1. Total Protein Levels of Caco-2 Cells before and after $24 \mathrm{~h}$ of Treatment with Grain Sorghum Dry Distiller's Grain Lipids

\begin{tabular}{lc}
\hline lipid treatment $(\mu \mathrm{g} / \mathrm{mL})$ & total protein levels ${ }^{\mathrm{a}}(\mu \mathrm{g} / \mathrm{mL})$ \\
\hline 0 (control) $^{\mathrm{b}}$ & $107.5 \pm 5.8 \mathrm{a}$ \\
0 (control) $^{\mathrm{c}}$ & $151.1 \pm 5.0 \mathrm{~b}$ \\
400 & $154.2 \pm 8.0 \mathrm{~b}$ \\
500 & $145.7 \pm 7.2 \mathrm{~b}$ \\
600 & $145.6 \pm 7.4 \mathrm{~b}$
\end{tabular}

a. Results are expressed as the mean \pm standard error of the mean of total cellular protein (in $\mu \mathrm{g} / \mathrm{mL}$ ). Different letters represent results that are significantly different $(p<0.05)$.

b. Represents protein levels of Caco- 2 cells before $24 \mathrm{~h}$ treatment.

c. Represents protein levels of Caco-2 cells after $24 \mathrm{~h}$ treatment.

doses $(18,29-31)$. Darbon and Casagrande (31) attributed their results to the ability of biological systems to compensate for low-level toxicity of a bioactive agent but are overcome at higher treatment doses. More studies are needed to understand this low-dose response as these results may have important clinical implications. For the purpose of this study, higher GS-DDG lipid dosage levels that adversely affected proliferation $(400-600 \mu \mathrm{g} / \mathrm{mL})$ were used for the remaining experiments.

Colon cancer usually presents as hyperproliferation of the epithelial lining due to deregulated cell cycle arrest and/or the suppression of programmed cell death (apoptosis) $(24,31)$. Dietary components have in turn been shown to control such abnormal growth by causing tumor cell death and/or by regulating the cell cycle $(8,17,18,27-34)$. To understand in part the chemoprotective properties of GS-DDG lipids against Caco-2 proliferation, overall cell growth was determined by monitoring cellular protein levels prior to and after the $24 \mathrm{~h}$ treatment period (Table 1). Protein levels of the control and treated cells were significantly higher post-treatment compared to the control pretreatment, showing that the cells continued to grow. Considering that the control and the treated cells had comparable protein levels, the results suggest that GS-DDGs did not impact proliferation by inhibiting cell growth after $24 \mathrm{~h}$ of treatment.

Acute cytotoxic effects of the GS-DDG lipids were assessed by measuring percent dead cell counts relative to total cells counts (Table 2). Total cell counts were not significantly different between the control and any of the lipid treatments tested $(400,500$, and $600 \mu \mathrm{g} / \mathrm{mL}$
Table 2. Total and Percent Dead Cell Counts of Caco-2 Cells after $24 \mathrm{~h}$ Treatment with Grain Sorghum Dry Distiller's (GS-DDG) Grain Lipids

\begin{tabular}{llc}
\hline GS-DDG lipid $(\mu \mathrm{g} / \mathrm{mL})$ & total counts $^{\mathrm{a}}($ cells $/ \mathrm{mL})$ & dead cell counts $^{\mathrm{b}}(\%)$ \\
\hline blank & $2.27 \pm 0.38 \times 10^{5} \mathrm{a}$ & $6.58 \pm 0.61 \mathrm{a}$ \\
0 (control) & $1.14 \pm 0.21 \times 10^{5} \mathrm{~b}$ & $16.42 \pm 4.89 \mathrm{a}$ \\
400 & $9.93 \pm 2.05 \times 10^{4} \mathrm{~b}$ & $26.43 \pm 4.13 \mathrm{~b}$ \\
500 & $7.80 \pm 1.29 \times 10^{4} \mathrm{~b}$ & $25.62 \pm 8.99 \mathrm{~b}$ \\
600 & $9.35 \pm 2.13 \times 10^{4} \mathrm{~b}$ & $26.77 \pm 4.35 \mathrm{~b}$
\end{tabular}

a. Results are expressed as the mean \pm standard error of the mean (SEM) of total cell counts per $\mathrm{mL}$ of medium after staining with Trypan Blue. Different letters in the column represent results that are significantly different $(p<0.05)$.

b. Results are expressed as the mean \pm SEM of percent dead cell counts after staining with Trypan Blue. Different letters in the column represent results that are significantly different $(p<0.05)$.

of GS-DDG lipids), again indicating that the treated cells grew during the exposure period. However, the percent dead cells were higher for each treatment group compared to the control but were similar between GS-DDG lipid dosage levels. A loss of cellular membrane integrity in response to each GS-DDG lipid was confirmed with the LDH assay. As shown in Figure 2, a significant increase of the cellular protein, LDH, was detected in the medium for samples treated with the GS-DDG lipids, but the LDH level for the $400 \mu \mathrm{g} / \mathrm{mL}$ treated cells was significantly lower compared to the 500 and $600 \mu \mathrm{g} / \mathrm{mL}$ doses, which may signify greater protection with higher GS-DDG doses. In addition, LDH levels were not significantly different between the blank and the control, indicating that the micelles were not acutely cytotoxic to the cells (Figure 2). These results are supported by the cell count data (Table 2) as significantly higher total cell counts occurred for the blank (cells - micelles) compared to the control (cells + micelles) but the percentages of dead cells were similar between the two samples.

Because the dead cell counts accounted for only $10 \%$ of total cell count (Table 2), but overall viability was reduced by $25-50 \%$ as evidenced by the MTT results (Figure 1), the presence of apoptotic cells was determined by flow cytometry after staining with fluorescent isothiocyanate-annexin V (AV) and/or propidium iodide (PI). Cells were considered viable, early apoptotic, late apoptotic + necrotic, or necrotic for $\mathrm{AV}-/ \mathrm{PI}-$, and $\mathrm{AV}+/ \mathrm{PI}-, \mathrm{AV}+/ \mathrm{PI}+$, and $\mathrm{AV}-/ \mathrm{PI}+$ counts, respectively. Viable cell count decreased significantly for each dosage level compared to the control (by 12-40\%), but the cells treated 


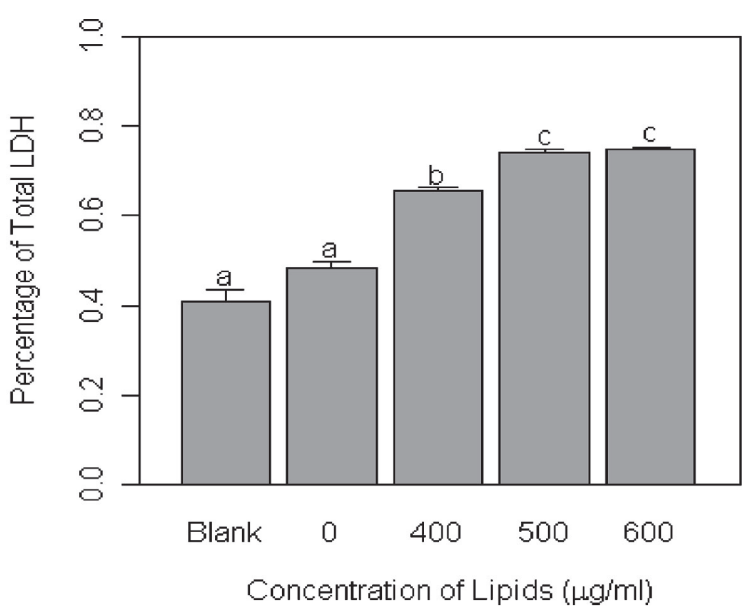

Figure 2. Percent of total lactate dehydrogenase (LDH) released from Caco-2 cells treated with grain sorghum dry distiller's (GS-DDG) lipids. Treatments included a blank, a control $(0 \mu \mathrm{g} / \mathrm{mL}$ GS-DDG lipids), and the cited treatments of GS-DDG treatments (in $\mu \mathrm{g} / \mathrm{mL}$ ) solublized in micelles. Each treatment was applied for $24 \mathrm{~h}$, and a sample was used to determine the LDH released from the cells. Results are expressed as the mean \pm standard error of the mean, and those that differ significantly $(p<0.05)$ are designated with different letters.

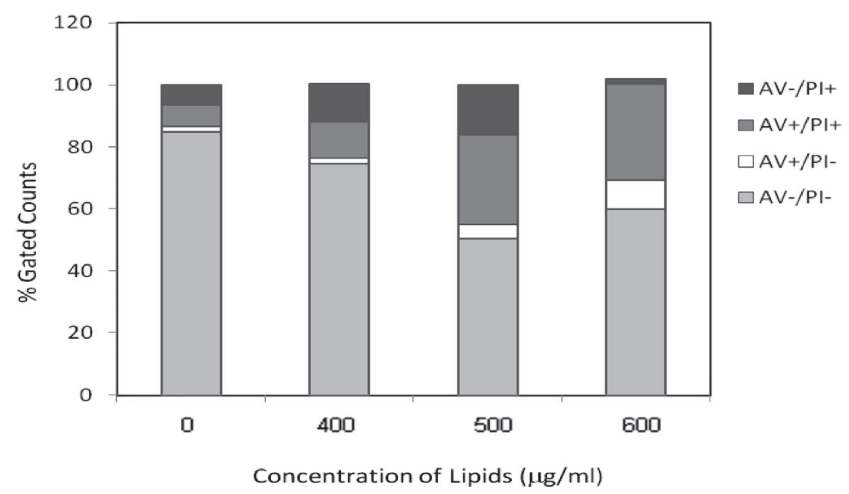

Figure 3. Fluorescence-activated cell results of Caco-2 cells after $24 \mathrm{~h}$ treatment with grain sorghum dry distiller's grain lipids (in $\mu \mathrm{g} / \mathrm{mL}$ ) (GSDDG). Each treatment, including a control $(0 \mu \mathrm{g} / \mathrm{mL}$ GS-DDG lipids), was applied for $24 \mathrm{~h}$, and a sample was used to determine the percent gated counts of cells that stained as annexin $\mathrm{V}(\mathrm{AV})-$ /propidium (PI)- (viable), $\mathrm{A} \mathrm{V}+/ \mathrm{PI}-$ (early apoptotic), $\mathrm{A} \mathrm{V}+/ \mathrm{PI}+$ (late apoptotic + necrotic), or $\mathrm{A} \mathrm{V}-/ \mathrm{PI}+$ (necrotic).

with $400 \mu \mathrm{g} / \mathrm{mL}$ GS-DDG lipids resulted in significantly higher viable counts with respect to the 500 and $600 \mu \mathrm{g} / \mathrm{mL}$ treatments (Figure 3 and Table 3). These preliminary results support the MTT data (Figure 1) when accounting for variability inherent to both assays. Similar to the Trypan Blue and \%LDH assays, staining of cells by PI is an indicator of the loss of plasma membrane integrity or necrotic cells. Although PI-stained cells were apparent by the FACs method (Figure 3), a population apoptotic cells was also detected after GS-DDG lipid treatment at significantly higher numbers compared to the control with the notable exception of the $400 \mu \mathrm{g} / \mathrm{mL}$ treated cells (Table 3 ). These results suggest that the $400 \mu \mathrm{g} / \mathrm{mL}$ dose may not be as efficacious as higher GS-DDG lipid levels as evidenced by the LDH data (Figure 2), but the 500 and $600 \mu \mathrm{g} / \mathrm{mL}$ doses resulted in 4-5 times and 2-7 times more cells in either early apoptotic (AV+/PI-) or necrotic $(\mathrm{A}+/ \mathrm{PI}+)$ stages, respectively.

Apoptotic cells exhibit several characteristic morphologic patterns, including maintenance of intact plasma membrane and activation of surface molecules that target the apoptotic cells for phagocytosis by
Table 3. Fluorescence-Activated Cell Results of Caco-2 Cells after $24 \mathrm{~h}$ Treatment with Grain Sorghum Dry Distiller's Grain Lipids ${ }^{a}$

\begin{tabular}{lcccc}
\hline $\begin{array}{l}\text { lipid treatment } \\
(\mu \mathrm{g} / \mathrm{mL})\end{array}$ & $\begin{array}{c}\mathrm{AV}-/ \mathrm{PI}- \\
(\%)\end{array}$ & $\begin{array}{c}\mathrm{AV}+/ \mathrm{PI}- \\
(\%)\end{array}$ & $\begin{array}{c}\mathrm{AV}+/ \mathrm{PI}+ \\
(\%)\end{array}$ & \multicolumn{1}{c}{$\begin{array}{c}\mathrm{AV}-/ \mathrm{PI}+ \\
(\%)\end{array}$} \\
\hline 0 (control) & $84.8 \pm 1.4 \mathrm{a}$ & $1.7 \pm 1.4 \mathrm{a}$ & $6.8 \pm 1.2 \mathrm{a}$ & $6.6 \pm 0.2 \mathrm{a}$ \\
400 & $74.4 \pm 1.7 \mathrm{~b}$ & $2.0 \pm 0.6 \mathrm{ab}$ & $11.7 \pm 2.1 \mathrm{ab}$ & $12.1 \pm 0.7 \mathrm{a}$ \\
500 & $50.2 \pm 1.1 \mathrm{c}$ & $\begin{array}{c}4.9 \pm 0.8 \mathrm{~b} \\
28.7 \pm 5.0 \mathrm{~b}\end{array}$ & $16.1 \pm 4.7 \mathrm{a}$ \\
600 & $57.1 \pm 4.2 \mathrm{c}$ & $10.4 \pm 1.8 \mathrm{~b}$ & $30.8 \pm 3.1 \mathrm{~b}$ & $1.65 \pm 0.5 \mathrm{a}$ \\
\hline
\end{tabular}

a. Results expressed as the mean \pm standard deviation of percent gated events of cells that stained as annexin $\mathrm{V}(\mathrm{AV})$-/propidium $(\mathrm{PI})-$ (viable cells), AV+/PI- (early apoptotic cells), AV+/PI+ (late apoptotic + necrotic cells), or AV-PI+ (necrotic cells). Different letters in a column represent results that are significantly different $(p<0.05)$.

Table 4. Levels of Simple Lipid Classes in Grain Sorghum Dry Distiller's Grain Lipids

\begin{tabular}{lc}
\hline lipid class & amounta $^{\mathrm{a}}(\mathrm{mg} / \mathrm{g})$ \\
\hline diacylglycerides $^{\mathrm{b}}$ & detected $^{\mathrm{e}}$ \\
sterols (free and esterified) $^{\text {tocopherols }}$ & $9.9 \pm 1.3$ \\
toldehydes and wax esters $^{\mathrm{d}}$ & $0.4 \pm 0.0$ \\
free fatty acids $^{\mathrm{d}}$ & $16.0 \pm 11.0$ \\
policosanols $^{\mathrm{a}}$ & $71.0 \pm 13.0$ \\
triacylglycerides $^{\mathrm{d}}$ & $39.0 \pm 7.7$ \\
hydrocarbons $^{\mathrm{d}}$ & $866.0 \pm 23.3$ \\
\hline
\end{tabular}

a. Results are expressed as the mean \pm standard deviation of $\mathrm{mg}$ of lipid class per gram of lipid.

b. Thin layer chromatography and densitometry.

c. High-performance liquid chromatography with ultraviolet detection.

d. Gas chromatography with a flame ionization detection.

d. High-performance liquid chromatography with evaporative light scattering detection.

e. Limit of quantitation $(0.5 \mathrm{mg} / \mathrm{g})$.

$\mathrm{f}$. Limit of quantitation $(0.8 \mathrm{mg} / \mathrm{g})$.

neighboring bodies (35). In contrast, necrotic cells demonstrate cell swelling and loss of membrane integrity culminating in the eventual release of inflammatory cellular contents. As a result, cancer treatment options triggering cell death by apoptosis are preferable to those that induce necrosis. It is unclear at this point whether the GS-DDG lipid directly induced necrosis or whether apoptotic cells proceeded to secondary necrosis due to the absence of a phagocytotic response in pure cultures. Nonetheless, the cytotoxic effect (caused by a necrotic and/ or an apoptotic response) was probably exhibited late in the $24 \mathrm{~h}$ treatment period before the cellular growth rate could be affected. Additional time course studies are needed to test this hypothesis.

GS-DDG Lipid Characterization Study. Physiochemical characterization of natural systems intended as FFN ingredient sources is needed to identify the constituents responsible for their health-promoting properties. Although other studies have reported the lipid composition of GS-DDGs $(2,4,5)$, bioactive agents can be affected by extraction conditions, sampling handling, and extended storage periods and are thus prone to lot-to-lot variability. Therefore, the crude lipid extract used for the previous study was characterized in our laboratory to determine potential bioactive agents responsible for the antiproliferation effect.

Several major simple lipid classes, including triacylglycerides, free fatty acids, policosanols, free sterols, and steryl esters, were initially detected with TLC, which were confirmed by HPLC-ELSD (data not shown). On the basis of the latter test, the most abundant lipid class was triacylglycerides $(866.0 \pm 23.3)$ followed by free fatty acids $(71.0 \pm 13)$ (Table 4). Fatty acid compositional analysis showed that these groups (in combination the sterol esters) were composed primarily of linoleic acid (C18:2) (Figure 4). Despite its being a potential pro-inflammatory compound, Sasaki et al. (36) reported that linoleic acid (100-400 $\mu \mathrm{g} /$ $\mathrm{mL}$ ) decreased the growth rate of colon cancer cell lines (Colo320 and MKN28) by $22-98 \%$. These results correlated with a reduction in tumor 


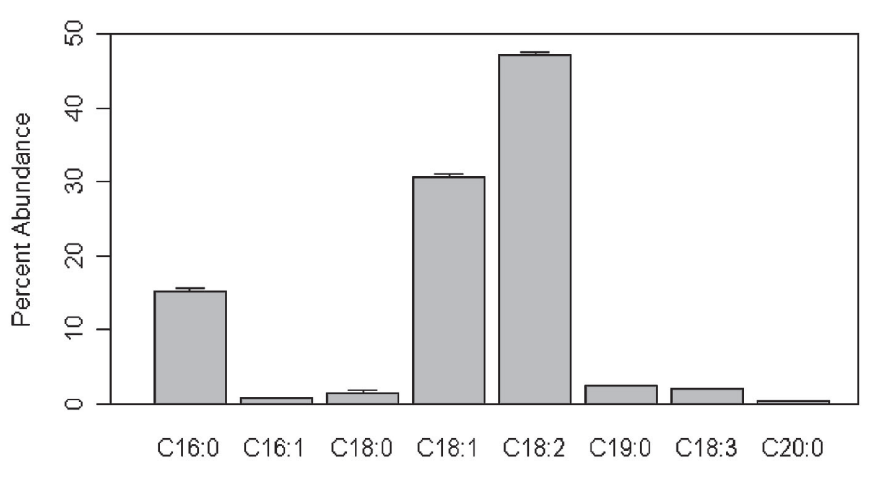

Fatty Acid

Figure 4. Percent abundance of fatty acids present in the grain sorghum dry distiller's grain lipids. The fatty acid profiles were determined using gas chromatography-flame ionization, and the relative peak area of each fatty acid was obtained. Values represent the mean \pm standard deviation of percent relative abundance of each fatty acid.

Table 5. Composition of Plant Sterols in Grain Sorghum Dry Distiller's Grain Lipids

\begin{tabular}{ll}
\hline isomer & amount $^{\mathrm{a}}(\mathrm{mg} / \mathrm{g})$ \\
\hline$\beta$-sitosterol & $4.1 \pm 0.5$ \\
stigmasterol & $4.2 \pm 0.5$ \\
campesterol & $1.7 \pm 0.3$ \\
total & $9.9 \pm 1.3$ \\
\hline
\end{tabular}

a. Results are expressed as the mean \pm standard deviation of $\mathrm{mg}$ sterol $/ \mathrm{g}$ of grain sorghum distiller's grain lipids.

development when treated and untreated Colo320 and MKN28 cells were injected into the peritoneal cavity of BALB/c nu/nu athymic mice. The GS-DDG lipid extract also contained relatively high levels of oleic acid (C18:1) (Figure 4), which has been shown to be a potential antiproliferative agent, albeit against breast cancer (37).

Moreover, GC analysis showed that the phytosterols (free and esterified) accounted for $9.9 \pm 1.3 \mathrm{mg} / \mathrm{g}$ of the lipid extract (Table 4) with $\beta$-sitosterol and stigmasterol present at equivalent levels followed by campesterol (Table 5). Awad and Fink (38) reported that $\beta$-sitosterol, and possibly stigmasterol and campesterol, increased apoptotic activity in cancer cells. On the basis of the results cited (Table 5) and the GSDDG lipid treatment levels used for this study, the $\beta$-sitosterol doses delivered to the cells were significantly lower (1-10 $\mathrm{nM} \beta$-sitosterol) than the 30-60 $\mu \mathrm{M}$ 7-hydroxysitosterol required to induce apoptosis in Caco-2 cells as reported by Roussi et al. (39).

As previously discussed, Campbell et al. (8) studied the antiproliferation effects of tocopherols against several colon cancer cell lines (SW480, HCT-15, HCT-116, and HT-29) at levels representing dietary and supplementation levels of $25-200 \mu \mathrm{M}$, respectively. a-Tocopherol did not significantly affect cell proliferation, whereas the lowest dosage of $\gamma$-tocopherol resulted in the higher dead counts of SW480 and HCT-116 cells. Analysis of the GS-DDG lipid extract did show the presence of a-tocopherol $(0.20 \pm 0.00 \mathrm{mg} / \mathrm{g})$ and $\gamma$-tocopherol $(0.19$ $\pm 0.01 \mathrm{mg} / \mathrm{g}$ ) at a total concentration of $0.39 \pm 0.01 \mathrm{mg} / \mathrm{g}$ (Table 4). Therefore, the levels of $\alpha$ - and $\gamma$-tocopherol in the $1000 \mu \mathrm{g} / \mathrm{mL}$ lipid treatment group were each $<0.5 \mathrm{nM}$, that is, again substantially lower than the effective doses reported in the literature.

Because preliminary data obtained in our laboratory demonstrated that other GS-DDG lipid extracts contained carotenoids, particularly $\beta$-carotene (data not shown), the sample used for this study was tested accordingly. As potent antioxidants, carotenoids can deactivate free radicals that damage the basic structure of cells and thus lead to cancer (40). However, carotenoids were not detected in the GS-DDG lipid sample under the conditions of the test and thus could not account for the cited antiproliferation results. These compounds may have been lost during processing or may not be present in the GS cultivar that served as the raw material.

Other lipid components were detected in the GS-DDG lipid sample that to our knowledge have yet to be evaluated for their anticancer properties. For example, total levels of policosanols accounted for $39.0 \pm 7.7 \mathrm{mg} / \mathrm{g}$ of the extract (Table 4). Compositional analysis of their chain lengths was not completed in our laboratory, but Hwang et al. (4) confirmed that the wax fraction of GS-DDG was composed of C28 and C30 chain policosanols, which is most likely the compositional profile of the sample used in this study. In addition, two unknown bands were detected via the TLC method. Hwang et al. (41) reported similar TLC banding patterns for lipids extracted from the GS whole kernel and confirmed that a band with the same $R_{f}$ value as one of the unknown GS-DDG lipid groups was due to long-chain aldehydes. Moreover, Hwang et al. reported that long-chain aldehydes accounted for $23 \%$ of the wax fraction isolated from GS-DDG samples (4). Additionally, in-house analysis with HPLC-ELSD showed an intense band at the same retention time as the external aldehyde standard, albeit wax/steryl esters also coeluted with the former lipid group (data not shown). More tests are needed to definitely identify the suspect TLC band, but the combined information suggests that it may be due to long-chain aldehydes. The other unknown TLC band has yet to be identified by our laboratory or by any other published reports. Diacylglycerides and hydrocarbons were further detected in the extract but at levels lower than the quantitation capability of the assay (Table 4).

In summary, the physiochemical characterization study confirmed that the sample contained lipid-based constituents that have been linked to potent anticancer properties, but many were significantly below the effective concentrations reported in the literature with the notable exception of linolenic and oleic acid. The antiproliferation benefits of the GS-DDG extracts could be caused by synergistic and/or additive effects of the components as has been reported for many types of natural systems (42-44). The GS-DDG lipid extract also contains other types of lipids that have not been studied for their antiproliferation properties but may indeed be potent cancer prevention agents. Nonetheless, this project is significant as it is the first to report the chemoprotective potential of the GS-DDG lipid extract. Additional studies are needed to further elucidate the mechanisms by which GSDDG lipids exert their antiproliferation properties against multiple types of cancers and to identify the specific component or combination of components responsible in order to develop this currently underutilized cereal and its coproducts as safe and effective source of ingredients for functional foods.

\section{References}

1. Hoffman, L. A.; Baker, A.; Foreman, L.; Young, E. Feed Grains Backgrounder, USDA Economic Research Service, 2007; available at http://www.ers.usda.gov/Publications/FDS/2007/03Mar/ FDS07C01/

2. Wang, L.; Weller, C. L; Schlegel, V. L; Carr, T. P.; Cuppett, S. L.Supercritical $\mathrm{CO}_{2}$ extraction of lipids from grain sorghum dried distillers grains with solubles Bioresour. Technol. 2008, 99, 1373- 1382

3. Federal Register. Revised Renewable Fuel Standard for 2008, Issued Pursuant to Section 211(o) of the Clean Air Act as amended by the Energy Independence and Security Act of 2007, EPA 73 Fed. Regist. $2008,8,665$.

4. Hwang, K. T.; Weller, C. L.; Cuppett, S. L.; Hanna, M. A.Policosanol contents and composition of grain sorghum kernels and dried distillers grains Cereal Chem. 2004, 81, 345- 349

5. Wang, L.; Weller, C. L; Schlegel, V. L; Carr, T. P.; Cuppett, S. L.Comparison of supercritical $\mathrm{CO}_{2}$ and hexane extraction of lipids from sorghum distillers grains Eur. J. Lipid Sci. Technol. 2007, 109, 567- 574

6. Awad, A. B.; Williams, H.; Fink, C.Phytosterols reduce in vitro metastatic ability of MDA-MB-231 human breast cancer cells Nutr. Cancer 2001, 40, 157- 164 
7. Stefani, E. D.; Boffetta, P.; Ronco, A. L.; Brennan, P.; Deneo-Pellegrini, H.; Carzoglio, J. C.; Mendilaharsu, M.Plant sterols and risk of stomach cancer: a case-control study in Uruguay Nutr. Cancer 2000, 37, 140- 144

8. Campbell, S. E.; Stone, W. L.; Lee, S.; Whaley, S.; Yang, H.; Qui, M.; Goforth, P.; Sherman, D.; McHaffie, D.; Krishnan, K.Comparative effects of RRR- $\alpha$ - and RRR- $\gamma$-tocopherol on proliferation and apoptosis in human colon cancer cell lines BMC Cancer 2006, 6, 1- 14

9. Moral, R.; Solanas, M.; Garcia, G.; Colomer, R.; Escrich, E.Modulation of EGFR and neu expression by n-6 and n-9 highfat diets in experimental mammary adenocarcinomas Oncol. Rep. $2003,10,1417-1424$

10. Isaacson, C.The change of the staple diet of black South Africans from sorghum to maize (corn) is the cause of the epidemic of squamous carcinoma of the oesophagus Med. Hypotheses 2005, 64, 658- 660

11. Chen, F.; Cole, P.; Mi, Z.; Xing, L.-Y.Corn and wheat-flour consumption and mortality from esophageal cancer in Shanxi, China Int. J. Cancer 1993, 53, 902- 906

12. Van Rensburg, S. J.Epidemiologic and dietary evidence for a specific nutritional predisposition to esophageal cancer J. Natl. Cancer Inst 1981, 67, 243- 251

13. Hasler, C.The changing face of functional foods J. Am. Coll. Nutr. 2002, 19, 406S- 506 S

14. Brower, V.A nutraceutical a day may keep the doctor away EMBO J. 2005, 6, 708- 711

15. Wang, L.; Weller, C. L.; Hwang, K. T.Extraction of lipids from grain sorghum DDG Trans. ASAE 2005, 48, 1883- 1888

16. Wijeratne, S.; Cuppett, S.; Schlegel, V.Hydrogen peroxide induced oxidative stress damage and antioxidant enzyme response in Caco-2 human colon cells J. Agric. Food Chem. 2005, 53, 8768- 8774

17. Zhu, Q.; Meisinger, J.; Van Thiel, D. H.; Yang, Z.; Mobarhan, S.Effects of soybean extract on the morphology and survival of Caco-2, SW620, and HT-29 cells Nutr. Cancer 2002, 42, 131- 140

18. Kampa, M.; Alexai, V.-I.; Notas, G.; Nifli, A.-P.; Nistikaki, A.; Hatzoglou, A.; Bakogeogou, E.; Kouimtzoglou, E.; Blekas, G.; Boskou, D.; Gravanis, A.; Castanas, E.Antiproliferative and apoptotic effects of selective phenolic acids on T47D human breast cancer cells: potential mechanisms of action Breast Cancer Res. 2004, 6, R63- R74

19. Bruni, R.; Guerrini, A.; Scalia, S.; Romagnoli, C.; Sacchetti, G.Rapid techniques for the extraction of vitamin $\mathrm{E}$ isomers from Amarathus caudatus seeds: ultrasonic and supercritical fluid extraction Phytochem. Anal. 2002, 13, 257- 261

20. Craft, N. E. Chromatographic techniques for carotenoid separation. In Current Protocols in Food Analytical Chemistry; Wrolstad, R., Ed.; Wiley: New York, 2001; Vol. 2, pp F2.3.1- F2.3.15.

21. Schneider, C. L.; Crowles, R. L.; Stuefer-Powell, C. L.; Carr, T. P.Dietary steric acid reduces cholesterol absorption and increases endogenous cholesterol excretion in hamsters fed cereal-based diets J. Nutr. 2000, 130, 1232- 1238

22. American Oil Chemists Society. Sampling and Analysis of Commercial Fats and Oils; Urbana, IL, 2001; Official Method Ce 1b-89.

23. Center for Disease Control and Prevention. Colon Cancer Statistics, Atlanta, GA, 2006; available at http://www.cdc.gov/cancer/ colorectal/

24. Potten, C. S.Epithelial cell growth and differentiation. II. Intestinal apoptosis Am. J. Physiol. 1997, 273, G253- 257

25. Gryfe, R.; Swallow, C.; Bapat, B.; Redston, M.; Gallinger, S.; Couture, J.Molecular biology of colorectal cancer Curr. Probl. Cancer 1997, 21, 233- 300

26. Bohn, T.; Tian, Q.; Chitchumroonchokchai, C.; Failla, M. L.; Schwartz, S. J.; Cotter, R.; Waksman, J. A.Supplementation of test meals with fat-free phytosterol products can reduce cholesterol micellarization during simulated digestion and cholesterol accumulation by Caco- 2 cells J. Agric. Food Chem. 2007, 55, 267- 272

27. Yang, J.; Meyers, K. J.; van der Heide, J.; Liu, R. H.Varietal differences in phenolic content and antioxidant and antiproliferative ac- tivities of onions J. Agric. Food Chem. 2004, 52, 6787- 6793

28. Kuntz, W.; Wnzel, U.; Daniel, H.Comparative analysis of the effects of flavonoids on proliferation, cytotoxicity and apoptosis in human colon cancer cell lines Eur. J. Nutr. 1999, 38, 133- 142

29. Fimognari, C.; Berti, F.; Nusse, M.; Cantelli-Fort, B.; Hrelia, P.Induction of apoptosis in two human leukemia cell lines as well as differentiation in human promyelocytic cells by cyanidin-3-O- $\beta$ glucopyranoside Biochem. Pharmacol. 2004, 67, 2047- 2056

30. Yang, L.; Browning, J. D.; Awika, J. M.Sorghum 3-deosyanthocyanins possess strong phase II enzyme inducer activity and cancer cell growth inhibition properties J. Agric. Food Chem. 2009, 57, 1797- 1840

31. Casagrande, F.; Darbon, J. M. Effects of structurally related flavonoids on cell cycle progression of human melanoma cells: regulation of cyclin-dependent kinases CDK2 and CDK1. Biochem. Pharmacol. 2001, 61, 1205- 1215.

32. Nijveldt, R. J.; van Nood, E.; Vann Hoorn, E. C.; Boelens, P. G.; van Norren, K.; van Leeuwen, P. A. M.Flavonoids: a review of probable mechanisms of action and potential applications Am. J. Clin. Nutr. 2001, 74, 418- 425

33. Yi, W.; Fischer, J.; Akoh, C. C.Study of anticancer activities of muscadine grape phenolics in vitro J. Agric. Food Chem. 2005, 53, 8804- 8812

34. Netzel, M.; Netzel, G.; Cammerer, D. R.; Schieber, A.; Carle, R.; Simons, L.; Bitsch, I.; Bitsch, R.; Konczak, L.Cancer cell antiproliferation activity and metabolism of black carrot anthocyanins Innovative Food Sci. Emerging Technol. 2007, 8, 365- 372

35. Fink, S. L; Cookson, B. T.Apoptosis, pryoptosis, and necrosis: mechanistic description of dead and dying eukaryotic cells Infect. Immun. 2005, 73, 1907- 1916

36. Sasaki, T.; Fujii, K.; Yoshida, K.; Shimura, H.; Sasahira, T.; Ohmori, H.; Kuniyasu, H.Peritoneal metastasis inhibition by linoleic acid with activation of PPARg in human gastrointestinal cancer cells Virchows. Arch. 2006, 448, 422- 427

37. Menendez, J. A.; Vellon, L.; Colomer, R.; Lupu, R.Oleic acid, the main monounsaturated fatty acid of olive oil, suppresses Her-2/ neu (erbB-2) expression and synergistically enhances the growth inhibitory effects of trastuzumab (Herceptin) in breast cancer cells with Her-2/neu oncogene amplification Ann. Oncol. 2005, 16, 359- 371

38. Awad, A. B.; Fink, C. S.Phytosterols as anticancer dietary components: evidence and mechanism of action J. Nutr. 2000, 130, 2127- 2130

39. Roussi, S.; Gossé, F.; Aoudé-Werner, D.; Zhang, X.; Marchioni, E.; Geoffroy, P.; Miesch, M.; Raul, F.Mitochondrial perturbation, oxidative stress and lysosomal destabilization are involved in $7 \beta$-hydroxysitosterol and $7 \beta$-hydroxycholesterol triggered apoptosis in human colon cancer cells Apoptosis 2007, 12, 87- 96

40. Kim, Y.; Lian, F.; Yeum, K. J.; Chongviriyaphan, N.; Choi, S. W.; Russell, R. M.; Wang, X. D.The effects of combined antioxidant ( $\beta$-carotene, a-tocopherol and ascorbic acid) supplementation on antioxidant capacity, DNA single-strand breaks and levels of insulin-like growth factor-1/IGF-binding protein 3in the ferret model of lung cancer Int. J. Cancer 2007, 120, 1847- 1854

41. Hwang, K. T.; Cuppett, S. L.; Weller, C. L.; Hanna, M. A.; Shoemaker, R.Aldehydes in grain sorghum wax J. Am. Oil Chem. Soc. 2002, 79, 529- 533

42. Zhou, J.-R.; Yu, Lunyin, Y.; Zhong, Y.; Blackburn, G. L.Soy phytochemicals and tea bioactive components synergistically inhibit androgen-sensitive human prostate tumors in mice J. Nutr. 2004, 133, $516-521$

43. Seeram, N. P.; Adams, L. S.; Hardy, M. L.; Herber, D.Total cranberry extract versus its phytochemical constituents: antiproliferative and synergistic effects against human tumor cell lines J. Agric. Food Chem. 2004, 52, 2512- 2517

44. Shi, J.; Kakuda, Y.; Yeung, D.Antioxidative properties of lycopene and other carotenoids from tomatoes: synergistic effects Biofactors 2008, 21, 203- 210 